\title{
ANALYSIS OF WILLINGNESS TO LEND IN PEER-TO-PEER LENDING APPLICATIONS
}

\author{
Abdullatif Zaky \\ Business School, IPB University, Indonesia \\ Purnaningsih Ninuk \\ Department of Communication Science and Community Development, \\ Faculty of Human Ecology, IPB University, Indonesia \\ Simanjuntak Megawati \\ Department of Family and Consumer Sciences, Faculty of Human Ecology, \\ IPB University, Indonesia \\ *E-mail: zakyabdullatif@gmail.com
}

\begin{abstract}
Peer-to-Peer Lending (P2P) applications were developed as an alternative funding solution, mainly for small-medium enterprises. $\mathrm{P} 2 \mathrm{P}$ can also be a promising alternative investment instrument. The significant gap between the number of lenders and borrowers is as a major issue that has been identified in the P2P of Indonesia. Therefore, the analysis of factors affecting willingness to lend in P2P lending needs to be done. The purpose of this study is to identify the socioeconomic characteristics of lenders, lenders perspective on familiarity, service quality, security protection, borrowers' reputation, borrowers' information, perceived benefits, perceived risk, trust to the borrower, trust to the intermediary, and willingness to lend in P2P lending applications. A total of 109 respondents filled out online questionnaires distributed through several media with the criteria of Indonesian citizens with investment experience in P2P. Descriptive and crosstab analysis was applied in this study. Based on the result, the impression that the borrowers will keep their promises (TB3), the system/ policy applied in the P2P platform to protect the interest of lenders ( $\mathrm{TI} 2$ ), the sense of security upon making transactions in P2P (SP 1), more attractive investment returns (PB 3) and quality assurance of prospective borrowers (SQ 4) are the most important factors affecting lenders willingness to lend.
\end{abstract}

\section{KEY WORDS}

Trust, willingness to lend, peer-to-peer lending, fintech.

Peer-to-Peer Lending (P2P) applications develop rapidly, along with the presence of various information technology-based financial innovations (Fintech) in Indonesia. P2P was created as an alternative funding solution for small, micro and medium enterprises (MSMEs) as well as individuals. P2P can also play a role as a promising alternative investment instrument for people who want to diversify their portfolios.

The definition of peer-to-peer lending, according to the Financial Services Authority (OJK, 2017) is the organization of financial services that connects lenders and loan recipients in the context of making a loan agreement to borrow in IDR on an electronic basis through the internet network. Lenders and borrowers are the main target group of all peer-topeer lending activities. The peer-to-peer lending intermediary site acts as an intermediary that connects lenders and borrowers in one web site. Lenders look for opportunities to invest money with the highest return possible at the desired level of risk. On the other hand, loan recipients expect loans with relatively calm conditions compared to other funding sources. The primary target recipients of loans from peer-to-peer lending are MSMEs with limited access to financial services due to the complex characteristics of MSMEs (Rosavina, 2018).

The purpose of this study is to identify the socioeconomic characteristics of lenders, familiarity, service quality, the security of protection, borrower reputation, borrower 
information, perceived benefits, perceived risk, trust to the borrower, trust to the intermediary, and willingness to lend in P2P lending applications.

\section{METHODS OF RESEARCH}

The study was conducted for three months from October 2019 to January 2020. Primary data were obtained through the distribution of online questionnaires aimed at respondents who invested in a peer-to-peer lending platform.

The sampling technique used in this study was purposive sampling. A total of 326 respondents participated in filling out online questionnaires distributed through social media and P2P lending forums in Indonesia. However, only 109 respondents met the criteria as lenders.

Primary data collection is done using an instrument in the form of an online questionnaire with the help of Google Form. Types of questions in this research consisted of both open-ended and close-ended questions. The questionnaire was divided into three parts: screening, respondent profile, and the main questions related to research variables.

Respondent profile data includes age, last education, gender, occupation, monthly income, and P2P applications that have been or are currently in use. The scale used is a Likert scale with five levels, namely (1) strongly disagree, (2) disagree, (3) neutral, (4) agree, and (5) strongly agree. Indicator variables used in this study are replications of the model used in the study of Zhang et al. (2014) and Chen et al. (2014) with additional indicator variables, namely the perceived benefit as an indicator variable for trust to borrowers (Pavlou and Gefen, 2004).

The reliability test of each variable in this study was measured using Cronbach's alpha so that inconsistent indicators could be detected (Malhotra, 2010). The test results show the Cronbach alpha coefficient on each variable above 0.60 which indicates that all variables are reliable namely familiarity (FM) 0.82 , service quality $(S Q) 0.69$, security protection (SP) 0.82 , borrower reputation (SC) 0.69, borrower information (IQ) 0.88, perceived risk (PR) 0.70, perceived benefits (PB) 0.89, trust in administrators (IT) 0.73, trust in borrowers (TB) 0.70, and interest in lending (WL) 0.70 .

Descriptive analysis has been applied using the average score and percentage method. Descriptions of indicator variables are grouped as agree and disagree answers. Answers (1) strongly disagree and (2) disagree are classified as disagreeing answers, while answers (3) are neutral, and answer (4) agree and (5) strongly agree are classified as agreeing on answers.

\section{RESULTS OF STUDY}

Respondents' demographic data includes gender, age, domicile, occupational category, monthly income, and final education. According to Estelami (1998), demographic characteristics such as age, income, and gender are often thought to affect product knowledge, shopping experience, and general buying behavior in most product or service categories. They are often used as a basis for market segmentation. In the case of P2P lending, lenders are perceived as consumers who buy products in the form of investment instruments.

Based on gender, the percentage of female respondents is relatively lower than the percentage of male respondents although the difference is not significant. These results are consistent with the research results of Montford and Goldsmith (2016) that women tend to be more conservative in investing and rely on accumulated savings over a more extended period than men. Total respondents were male, 62 respondents or 56.88 percent, while female lenders were 47 respondents or 43.12 percent. Based on the age group, the majority of respondents which counts to 58.72 percent aged between 25 to 29 years, followed by the second major age group of 30 to 34 years by 27.52 percent.

The age of the youngest respondent in this study was 18 years, while the age of the oldest respondent was 44 years. Furthermore, the cross-tabulation analysis was carried out 
to determine the relationship between lending willingness and the age group of respondents. The chi-square test results in Table 1 showed a p-value of 0.9762 , higher than 0.05 , which leads to a conclusion that there is no correlation between the respondent's age group and willingness to lend.

Table 1 - Crosstab between Age Group and Willingness to Lend

\begin{tabular}{cccccc}
\hline \multirow{2}{*}{ Age Group } & \multicolumn{5}{c}{ Willingness to Lend } \\
\cline { 2 - 6 } & Agree & Neutral & Disagree & Total & p-value \\
\hline$<25$ & 3 & 1 & 0 & 4 & \\
$25-29$ & 39 & 23 & 3 & 65 & \\
$30-34$ & 19 & 10 & 1 & 30 & 0.9762 \\
$35-40$ & 5 & 3 & 0 & 8 & \\
$>40$ & 2 & 0 & 0 & 2 & \\
Total & 68 & 37 & 4 & 109 & \\
\hline
\end{tabular}

Based on their domicile, the majority of respondents settled in DKI Jakarta, which counts to 82 respondents or 88.07 percent of the total respondents. All respondents settled in Java which covered the Greater Jakarta Area with a total of 99 respondents or 90.83 percent, Bandung by 2.75 percent, Pekalongan by 0.92 percent, and Semarang by 5.50 percent. Based on job categories, respondents are divided into four job categories, namely state-owned enterprises (BUMN) employees, private employees (PE), Civil Servants (PNS), and entrepreneurs (EP). Data shows that the majority of respondents, namely 96 respondents or 88.07 percent of the total respondents were private employees, followed by the entrepreneurial category of 10 respondents or about 9.17 percent of the total respondents. Respondents in the category of BUMN and PNS Employees rank last in 1.83 percent for BUMN employees and 0.92 percent for civil servants. Cross-tabulation analysis has been carried out to see whether there is a correlation between lending willingness and respondent occupational categories. Chi-square test results showed a p-value of 0.0128 , lower than 0.05 , which indicates a correlation between the respondent's profession and willingness to lend. Cross tabulations of willingness to provide loans and respondent occupational categories are listed in Table 2.

Table 2 - Crosstab of Occupational Categories on Willingness to Lend

\begin{tabular}{cccccc}
\hline Occupation & \multicolumn{5}{c}{ Willingness to Lend } \\
\cline { 2 - 6 } & Agree & Neutral & Disagree & Total & p-value \\
\hline State-Owned Enterprises & 0 & 1 & 1 & 2 & \\
Private Employees & 60 & 34 & 2 & 96 & 0.0128 \\
Civil Servants & 1 & 0 & 0 & 1 & \\
Entrepreneurs & 7 & 2 & 1 & 10 & \\
Total & 68 & 37 & 4 & 109 & \\
\hline
\end{tabular}

Respondents were divided into five monthly income categories from less than 5 million IDR, 5-10 million IDR, 10-20 million IDR, 20-50 million IDR, to more than 50 million IDR. The dominating category of 42 respondents or 38.53 percent of total respondents earns 5 to 10 million IDR per month followed by income categories of less than 5 million IDR which counts to 31 respondents or 28.44 percent and income categories of 10 to 20 million IDR of 25 respondents or 22.94 percent of total respondents.

Table 3 - Crosstab of Income Categories on Willingness to Lend

\begin{tabular}{cccccc}
\hline \multirow{2}{*}{ Income Categories } & \multicolumn{5}{c}{ Willingness to Lend } \\
\cline { 2 - 6 } & Agree & Neutral & Disagree & Total & p-value \\
\hline <= IDR 5 million & 19 & 12 & 0 & 31 & \\
IDR.5-10 million & 25 & 15 & 2 & 42 & \\
IDR. 10- 20 million & 17 & 7 & 1 & 25 & 0.3611 \\
IDR. 20-50 million & 5 & 0 & 1 & 6 & \\
>= IDR. 50 million & 2 & 3 & 0 & 5 & \\
Total & 68 & 37 & 4 & 109 & \\
\hline
\end{tabular}


A cross-tabulation analysis was carried out to see the relationship between lending willingness and respondents' income categories (Table 3). Chi-square test results showed a $\mathrm{p}$-value of 0.3611 , higher than 0.05 . So it can be concluded that there is no relationship between respondents' income and willingness to lend.

Based on the highest level of education, respondents with bachelor's degree were dominating with the counted number of 70 respondents or 64.22 percent of the total respondents. Respondents with high school background, vocational school, and equivalent rank second with a total count of 16 respondents or 14.68 percent. Furthermore, the category of respondents with Diploma or equivalent ranked 3rd with a total count of 13 respondents or 14.68 percent of the total respondents. On the other hand, the total number of respondents with a Master's degree was eight respondents or 7.34 percent of the total respondents, and two respondents or 1.83 percent holds a Doctorate. This finding is consistent with Sumarwan's (2014) opinion that consumers with higher levels of education tend to be more sensitive to information when compared to consumers with lower levels of education.

Table 4 - Crosstab Analysis of Education Level on Willingness to Lend

\begin{tabular}{cccccc}
\hline Education Level & \multicolumn{5}{c}{ Willingness to Lend } \\
\cline { 2 - 6 } & Agree & Neutral & Disagree & Total & $\mathrm{p}$-value \\
\hline Diploma (D3) & 11 & 0 & 2 & 13 & \\
S1 / Bachelor & 44 & 25 & 1 & 70 & 0.0465 \\
S2 / Master & 4 & 3 & 1 & 8 & \\
S3 / Doctoral & 1 & 1 & 0 & 2 & 16 \\
High School/ equivalent & 8 & 8 & 0 & 109 & \\
Total & 68 & 37 & 4 &
\end{tabular}

The cross-tabulation analysis was performed to see the correlation between the willingness to lend and the level of education of the respondents (Table 4). Chi-square test results showed a p-value of 0.0465 , lower than 0.05 . So it can be concluded that there is a significant correlation between the educational level of respondents and willingness to lend.

The results of this research survey regarding the indicator variable of familiarity are presented in Table 5. Familiarity refers to how closely lenders know the intermediary through the interaction process. The more often the process of interaction between the lender and the intermediary occurs, the lender is more familiar with the behavior pattern of the intermediary so that the lender can predict the behavior of the intermediary in the future (Kim et al., 2008).

Table 5 - Descriptive Statistics of Familiarity

\begin{tabular}{|c|c|c|c|c|}
\hline $\begin{array}{l}\text { Code } \\
\text { FM1 }\end{array}$ & $\begin{array}{l}\text { Indicators } \\
\text { Familiar with the available features }\end{array}$ & $\begin{array}{l}\text { Average } \\
3.91\end{array}$ & $\begin{array}{l}\text { Agree }(\%) \\
94.50\end{array}$ & $\begin{array}{l}\text { Disagree }(\%) \\
5.50\end{array}$ \\
\hline FM2 & $\begin{array}{l}\text { Know how to display a list of prospective borrowers and loan } \\
\text { details }\end{array}$ & 3.90 & 94.50 & 5.50 \\
\hline $\begin{array}{l}\text { FM3 } \\
\text { FM4 }\end{array}$ & $\begin{array}{l}\text { Know how to deposit/withdraw } \\
\text { Know how to display investment portfolio in P2P }\end{array}$ & $\begin{array}{l}4.03 \\
3.93\end{array}$ & $\begin{array}{l}96.33 \\
95.41\end{array}$ & $\begin{array}{l}3.67 \\
4.59\end{array}$ \\
\hline
\end{tabular}

The lowest average score is found in the FM2 indicator variable with a value of 3.90 , and the percentage of answers agreed at 94.5 percent. Thus it can be concluded that the majority of respondents are familiar with the P2P lending application used. These results indicate that most P2P lending providers succeeded in creating a user interface and user experience that was good enough so that lenders easily understood the features available and accessed these features (Gefen 2000; Gefen, Benbasat, and Pavlou 2008; Lu, Zhao, and Wang 2010).

Survey results regarding service quality indicator variables are presented in Table 6 . Based on references from LeyLand, Pitt, and Watson (1998), service quality can be interpreted as the quality of functions and services provided by the intermediary in order to improve the quality of customer experience. Quality of service in the context of e-business, including P2P lending and traditional e-commerce, refers to several aspects including 
performance, access, security, sensation, and information (Janda, Trocchia, and Gwinner 2002; Kim and Ko 2012) respectively. Each represented by a question in a questionnaire adapted from the research of Kim et al., (2008).

Table 6 - Descriptive Statistics of Service Quality

\begin{tabular}{lllll}
\hline Code & Indicator & Average & Agree (\%) & Disagree (\%) \\
\hline SQ1 & The intermediary provides a reliable service & 3.86 & 96.33 & 3.67 \\
SQ2 & Able to access features in the platform whenever needed & 3.91 & 93.58 & 6.42 \\
SQ2 & Customer service is always ready to help & 3.56 & 91.74 & 8.26 \\
SQ4 & The intermediary guarantees the quality of prospective borrowers & 3.70 & 92.66 & 7.34 \\
\hline
\end{tabular}

The majority of respondents agreed that the organization provided a good and reliable service quality. This is indicated by the average score of questions greater than 3.56 and the percentage of answers that agree is greater than 91.74 percent.

Survey results regarding safeguard safety indicator variables are presented in Table 7. Safeguard security refers to the lender's perception that the internet-based provider or service provider has fulfilled several security requirements such as authentication, integrity, encryption, and non-repudiation (Kim et al., 2008).

Table 7 - Descriptive Statistics of Security Protection

\begin{tabular}{llllll}
\hline Code & Indicator & Average & Agree (\%) & Disagree (\%) \\
\hline SP1 & $\begin{array}{l}\text { Sense of security when making transactions in the P2P } \\
\text { application }\end{array}$ & 3.68 & 94.50 & 5.50 \\
SP2 & $\begin{array}{l}\text { The organizer applies adequate security measures } \\
\text { SP3 }\end{array}$ & $\begin{array}{l}\text { A perceived sense of security with the available electronic } \\
\text { payment systems }\end{array}$ & 3.71 & 94.50 & 5.50 \\
\end{tabular}

The respondent's positive response to the questions raised in the questionnaire related to the protection safety variable adopted from previous research (Chen et al., 2014; Kim et al., 2008; and Zhang et al., 2014) is valued at more than 94.5 percent with the most average score low of 3.68. This indicates that most respondents feel safe doing transactions on the P2P lending platform that is used.

Borrower's reputation refers to the borrower's potential resources that can be accessed through social networks in the P2P platform (Kim et al., 2008). 12.84 respondents disagreed that the borrower actively interacted on social media (Table 8). This happens because of the lack of information related to the borrower's social media accounts which have the potential to increase the lender's trust in the borrower (Zhang et al. 2014).

Table 8 - Descriptive Statistics of Borrower Reputation

\begin{tabular}{lllll}
\hline Code & Indicator & Average & Agree (\%) & Disagree (\%) \\
\hline SC1 & Borrowers actively interact on social media & 3.58 & 87.16 & 12.84 \\
SC2 & Lenders can interact with borrowers & 3.76 & 90.83 & 9.17 \\
SC3 & Borrowers have a good reputation and are respected & 3.71 & 97.25 & 2.75 \\
\hline
\end{tabular}

Quality of information that refers to lenders' perceptions about the accuracy and completeness of the information provided by borrowers in the loan list (Zhang et al., 2014; Chen et al., 2014). The lowest average value for the borrower information indicator variable is 3.63, with a percentage of 92.66 percent agree. This shows that most respondents agreed that the completeness and accuracy of the information provided by the organiser could be relied upon to make rational lending decisions (Chen et al. 2014; Zhang et al. 2014). Responses given by respondents to questions related to borrower information indicator variables are summarized in Table 9.

Respondents' answers to questions related to perceived risk indicator variables are summarized in Table 10. Perceived risk refers to creditor trusts about the possibility of losing their investment in the online loan market due to the inability of borrowers to repay their debts. 
Table 9 - Descriptive Statistics of Borrower Information

\begin{tabular}{lllll}
\hline Code & Indicator & Average & Agree (\%) & Disagree (\%) \\
\hline IQ1 & Reliable borrower information & 3.67 & 94.50 & 5.50 \\
IQ2 & Borrower information as a basis for decision making & 3.71 & 92.66 & 7.34 \\
IQ3 & Satisfaction with provided information & 3.63 & 92.66 & 7.34 \\
\hline
\end{tabular}

Table 10 - Descriptive Statistics of Perceived Risk

\begin{tabular}{lllll}
\hline Code & Indicator & Average & Agree (\%) & Disagree (\%) \\
\hline PR1 & Investing in P2P borrowers carries a higher risk of financial loss & 3.68 & 92.66 & 7.34 \\
PR2 & High risk of losing investment due to default & 3.73 & 92.66 & 7.34 \\
PR3 & Assessment of borrower's risk in P2P & 3.50 & 87.16 & 12.84 \\
\hline
\end{tabular}

Previous studies have confirmed that perceived risk has a substantial impact on trust and purchase intentions in online businesses (Gefen et al., 2008). The average assessment score of respondents in this study of the potential risk of investing in P2P lending is 3.5 out of 5 which is categorized as quite high.

Respondents' answers to questions related to indicator indicators of perceived benefit are summarized in Table 11. Perceived benefit refers to user perceptions about the better value of service compared to those they used previously, which include economic benefits, comfort, and satisfaction (Yang \& Lee 2016). In addition to respondents' perceived risk, respondents' perceptions of the benefits offered by investing in P2P lending are also measured.

Table 11 - Descriptive Statistics of Perceived Benefit

\begin{tabular}{lllll}
\hline Code & Indicator & Average & Agree (\%) & Disagree (\%) \\
\hline PB1 & Investing in P2P borrowers brings higher profits & 3.74 & 96.33 & 3.67 \\
PB2 & The loan period proposed by the borrower is as expected & 3.76 & 94.50 & 5.50 \\
PB3 & $\begin{array}{l}\text { Investment returns on borrowers registered with P2P are more } \\
\text { attractive }\end{array}$ & 3.81 & 96.33 & 3.67
\end{tabular}

The majority of respondents agree that investing in P2P lending brings higher profits with a period that matches expectations. This is indicated by the average score of perception of benefits above 3.7 and the percentage of agreeing above 94 percent for all indicator variables. This is consistent with the results of research by Chen et al. (2015) regarding the effect of mitigating the perception of benefits on perceived risk.

Respondents 'answers regarding questions about the trust to the organizers are listed in Table 12. Trust to the Operator refers to the lenders' confidence that the P2P organizers have fulfilled their expectations including aspects of familiarity, security, service quality, and protection security (Zhang et al., 2018; Chen et al., 2018).

Table 12 - Descriptive Statistics of Trust to Intermediary

\begin{tabular}{lllll}
\hline Code & Indicator & Average & Agree (\%) & Disagree (\%) \\
\hline TI1 & The P2P system can protect the interests of lenders & 3.61 & 91.74 & 8.26 \\
TI2 & Policies in P2P applications protect the interests of lenders & 3.72 & 94.50 & 5.50 \\
TI3 & The organizer is trying to meet the needs of its users & 3.71 & 95.41 & 4.59 \\
\hline
\end{tabular}

The conclusion was drawn that most respondents gave trust to the organizers. This is evidenced by the average score above 3.61 for the trust variable to the organizer, followed by the percentage of answers agree with the percentage above 91.74 percent for each indicator variable.

Responses related to questions regarding the trust variable to the borrower are listed in Table 13. Trust to the borrower refers to the lender's trust in the borrower including aspects of the accuracy of the information, reputation, perceived risk and perceived benefits expected from the borrower (Zhang et al., 2018; Chen et al. ., 2018). Most respondents showed their confidence in the borrower. This is evidenced by the average score above 3.60 for the 
variable trust to the borrower followed by the percentage of answers agreed with the percentage value above 92.66 percent for each question.

Table 13 - Descriptive Statistics of Trust to Borrowers

\begin{tabular}{lllll}
\hline Code & Indicator & Average & Agree (\%) & Disagree (\%) \\
\hline TB1 & Borrowers on P2P platforms that can be trusted & 3.61 & 92.66 & 7.34 \\
TB2 & Borrowers give the impression that they will keep their promises & 3.60 & 93.58 & 6.42 \\
TB3 & Lenders believe the purpose of the borrower is for good & 3.71 & 95.41 & 4.59 \\
\hline
\end{tabular}

Answers to questions about the variable willingness to lend are listed in Table 14. Willingness to lend refers to the willingness of lenders to fund loan applications submitted by borrowers based on trust factors both organizers and borrowers (Zhang et al., 2018; Chen et al., 2018).

Table 14 - Descriptive Statistics of Willingness to Lend

\begin{tabular}{lllll}
\hline Code & Indicator & Average & Agree (\%) & Disagree (\%) \\
\hline WL1 & Interested in lending on P2P platforms & 3.78 & 96.33 & 3.67 \\
WL2 & The lender will bid on the loan application & 3.63 & 93.58 & 6.42 \\
WL3 & $\begin{array}{l}\text { Submitting a loan on the list of prospective borrowers is eligible } \\
\text { for funding }\end{array}$ & 3.71 & 96.33 & 3.67 \\
\hline
\end{tabular}

Most respondents agreed to lend on the P2P platform. This is evidenced by the average score above 3.63 for all variables willingness to lend, followed by the percentage of answers agree with a value above 96.33 percent.

\section{DISCUSSION OF RESULTS}

Trust is the most important factor that determines the success and sustainability of $e$ commerce (Gefen, Benbasat, and Pavlou, 2008). Lenders in P2P can be perceived as consumers who choose alternative investment products. Lenders are also exposed to several features offered by the organizer.

Kim, Ferrin and Rao (2008) define familiarity as to how closely lenders know the organizer through the process of interaction. The more often the process of interaction between the lender and the organizer occurs, the lender will become more familiar with the behavior pattern of the organizer so that the lender can predict the behavior of the organizer in the future based on the information they got in the previous interaction. According to Menon and Kahn (2002), in an e-commerce situation, consumers have a great chance to linger and explore further when getting a pleasant first experience. The behavior is closely correlated with positive familiarity. In a study conducted by Ha and Perks (2005), familiarity was defined as selected knowledge about a website that accumulated from consumer experience. A deep impression can be formed when consumers spend time searching for information on a website. The high level of familiarity with a brand results in greater satisfaction or trust unless the consumer has a negative perception of the brand.

Various studies have linked the quality of service with trust. Some researchers combine various measures of trust and security perceptions in a comprehensive measurement method of service quality in general, especially in the context of e-commerce (Janda et al., 2002). Quality of service affects the level of trust in service provider companies and in the service itself (Chumpitaz and Paparoidamis, 2007).

Safeguard security refers to the lender's perception that the internet-based provider or service provider has fulfilled several security requirements such as authentication, integrity, encryption, and non-repudiation (Kim, Ferrin, and Rao, 2008). The object that is exchanged in P2P is money; therefore the risk that may arise will be equivalent to the risks faced in other financial activities, especially those based online. The results of previous studies indicate that protection security is an important factor in making trust for activities that involve high risks such as the adoption of mobile payments (Kim et al., 2010) and e-commerce (Kim et al., 2008). According to Gefen et al. (2003), there is empirical evidence that structural assurance 
influences the emergence of trust in e-commerce systems. Structural assurance refers to consumers' perceptions about the existence of a security mechanism in an adequate ecommerce network system. Confidence in the structure arises because the user believes that the technology applied to the e-commerce system can protect so that the user believes that the transactions they make through the internet network can run safely (Mc Knight et al., 2002).

The quality of the information in question is the lender's perception of the accuracy and completeness of the information provided by the borrower in the loan list (Zhang et al., 2014; Chen et al., 2014). Due to constraints in terms of time and space, the lender collects information about the borrower only from the organizer through the loan register as a basis for assessing the suitability of the borrower. Thus, the information in the loan list is very reliable by the lender. Lenders tend not to be able to claim their rights through the legal system when facing bad loans. They should consider the information provided by the organizer in evaluating the feasibility and trust of the borrowers (Chen et al., 2014; Ding et al., 2019). Most lending websites provide features for uploading attachments. Borrowers can provide any material that they believe will increase their credibility. Thus, borrower information on the loan list becomes increasingly important in obtaining lender trust. The quality of loan list information can facilitate creditors' appraisal of the suitability of a request (Gavurova, Dujcak, Kovac, \& Kotásková, 2018). Information for this purpose includes the loan amount, duration, and interest rates. Information about the purpose of the loan is also considered important. If it is convincing and verifiable, the request is more reliable. Also, the quality of information serves as a proxy for assessing credibility. The quality of a good list of information reflects how serious, sincere, and professional the borrower is, which influences trust (Karahanna et al., 2003).

Regarding the reputation of the borrower, lenders only rely on all the information contained on the P2P lending website that they use as a basis for mining. This can be input for the organizer to provide more detailed features containing the borrower's reputation online in order to increase lenders' trust in the form of ratings and comments column.

Most respondents were indicated to be aware of the potential risk of loss or reduced investment value due to the potential for initial risk (default risk) or default. Nevertheless, respondents still gave a high value for the variable willingness to lend, indicating that respondents tend to ignore the potential risks by considering the potential benefits to be obtained (Chen et al. 2015).

Based on findings from research on e-commerce conducted by (Kim et al., 2008), the occurrence of transactions is also largely influenced by the perceived benefits expected by customers. Likewise, online loans, willingness to lend is influenced by the return that is expected to be received by lenders in the future. In this study, the focus is on two factors related to the expected return, namely: the interest rate and loan term proposed by the borrower. Furthermore, Pavlou and Gefen (2004) propose three categories of trust, including cognition-based trust consisting of perceived risk and information quality. The main objective of a lender is to obtain an investment return at a certain level of risk so that the lender will make sufficient judgment before making a lending decision.

In the service business, trust has been shown to play a vital role in consumer loyalty. When consumers trust the service provider, they will continue to use the service and will even recommend the service to other potential customers (Deng et al., 2010).

Lenders on P2P platforms need to choose similar offers from various borrowers. Because lenders often do not know the borrower, the formation of initial trust is essential. Because there is no repeated interaction between lenders and borrowers, initial trust is mainly based on cognition. Such cognitive-based trust relies on first cognitive cues that last for a short time (Mc Knight, Choudhury, and Kacmar, 2002).

\section{CONCLUSION}

The predominant characteristic of the respondents was male, aged 25-29 years, originating from DKI Jakarta, private employees, earning 5-10 million IDR per month and 
having an undergraduate education. There is a significant correlation between respondents' occupation and willingness to lend and significant correlation was also found between respondents' education level and willingness to lend. The majority of respondents are familiar with the P2P lending application used. These results indicate that P2P lending providers have succeeded in creating a good user interface and user experience so that lenders can easily understand the available features and access these features. Most respondents were also satisfied with the quality of services provided by the organizer. Furthermore, the organizer has provided good security and protection. The completeness and accuracy of the information provided are sufficient to make rational decisions regarding loan applications. Although the respondent is aware of the risk of impairment in investment due to default risk, the respondent's perception of the potential benefits to be gained keeps him willing to lend based on trust to both the organizer and the borrower.

\section{RECOMMENDATIONS}

Specific research on each P2P lending provider that has been registered and supervised by the OJK is recommended considering that each organizer has a different strategy in terms of branding, segmentation, and policy determination. Addition of other variables outside this study is also recommended. Examples of variables that need to be added include post-purchase experience, willingness to recommend, and evaluation on the net promoter score to see how far the lenders are interested in sharing the positive experiences gained after investing in P2P lending in Indonesia.

\section{REFERENCES}

1. Chen, Dongyu, Fujun Lai, and Zhangxi Lin. 2014. "A Trust Model for Online Peer-to-Peer Lending: A Lender's Perspective." Information Technology and Management 15(4):23954.

2. Chen, Dongyu, Hao Lou, and Craig Van Slyke. 2015. "Toward an Understanding of Online Lending Intentions: Evidence from a Survey in China." Communications of the Association for Information Systems 36:317-36.

3. Chumpitaz, R. C., \& Paparoidamis, N. G. (2007). Service quality, relationship satisfaction, trust, commitment and business-to-business loyalty. European journal of marketing. https://doi.org/10.1108/03090560710752429

4. Deng, Z., Lu, Y., Wei, K. K., \& Zhang, J. (2010). Understanding customer satisfaction and loyalty: An empirical study of mobile instant messages in China. International Journal of Information Management, 30(4), 289-300. https://doi.org/10.1016/j.ijinfomgt.2009.10.001

5. Ding, J., Huang, J., Li, Y., \& Meng, M. (2019). Is there an effective reputation mechanism in peer-to-peer lending? Evidence from China. Finance Research Letters, 30, 208-215. https://doi.org/10.1016/j.frl.2018.09.015

6. Estelami, H. (1998). The price is right... or is it? Demographic and category effects on consumer price knowledge. Journal of Product \& Brand Management. https://doi.org/10.1108/10610429810222886

7. Gavurova, B., Dujcak, M., Kovac, V., \& Kotásková, A. (2018). Determinants of Successful Loan Application on Peer-to-peer lending Market. Economics \& Sociology, 11(1), 85-99. https://doi.org/10.14254/2071-789x.2018/11-1/6

8. Gefen, David. 2000. "E-Commerce: The Role of Familiarity and Trust." Omega 28(6):725-37.

9. Gefen, David, Izak Benbasat, and Paula Pavlou. 2008. "A Research Agenda for Trust in Online Environments." Journal of Management Information Systems 24(4):275-86.

10. Ha, H.Y., \& Perks, H. (2005). Effects of Consumer Perceptions of Brand Experience on the Web: Brand Familiarity, Satisfaction and Brand Trust. Journal of Consumer Behaviour. 4(6): 438-452

11. Janda, Swinder, Philip J. Trocchia, and Kevin P. Gwinner. 2002. "Consumer Perceptions of Internet Retail Service Quality." International Journal of Service Industry Management 
13(5):412-31.

12. Karahanna, E., Gefen, D., \& Straub, D. W. (2003). Trust and TAM in Online Shopping: An Integrated Model. MIS Quarterly, 27(1), 51-90. https://doi.org/10.2307/30036519

13. Kim, Angella J. and Eunju Ko. 2012. "Do Social Media Marketing Activities Enhance Customer Equity? An Empirical Study of Luxury Fashion Brand." Journal of Business Research 65(10):1480-86.

14. Kim, Dan J., Donald L. Ferrin, and H. Raghav Rao. 2008. "A Trust-Based Consumer Decision-Making Model in Electronic Commerce: The Role of Trust, Perceived Risk, and Their Antecedents." Decision Support Systems 44(2):544-64.

15. Lu, Yaobin, Ling Zhao, and Bin Wang. 2010. "From Virtual Community Members to C2C E-Commerce Buyers: Trust in Virtual Communities and Its Effect on Consumers' Purchase Intention." Electronic Commerce Research and Applications 9(4):346-60.

16. Mc Knight, D. H., Choudhury, V., \& Kacmar, C. (2002). Developing And Validating Trust Measure for E-Commerce: An Integrative Typology. Information Systems Research, 13(3), 334-359.

17. Menon, S. \& Kahn, B. (2002). Cross-category effects of induced and pleasure on the internet shopping experience. Journal of Retailing. 78(1): $31-40$. https://doi.org/10.1016/S0022-4359(01)00064-1

18. Montford, William and Ronald E. Goldsmith. 2016. "How Gender and Financial SelfEfficacy Influence Investment Risk Taking." 40:101-6.

19. Pavlou, Paul A. and David Gefen. 2004. "Building Effective Online Marketplaces with Institution-Based Trust." Information Systems Research 15(1):37-59.

20. Yang, Q., \& Lee, Y. C. (2016). Critical factors of the lending intention of online P2P: Moderating role of perceived benefit. ACM International Conference Proceeding Series, 17-19-August-2016. https://doi.org/10.1145/2971603.2971618

21. Zhang, Tengwen, Mingfeng Tang, Yong Lu, and Dayong Dong. 2014. "Trust Building in Online Peer-to-Peer Lending." Journal of Global Information Technology Management 17(4):250-66. 